\title{
2-Heptyl-Formononetin Increases Cholesterol and Induces Hepatic Steatosis in Mice
}

\author{
Charlotte Andersen, ${ }^{1}$ Janne G. Schjoldager, ${ }^{1}$ Christian G. Tortzen, ${ }^{2}$ \\ Andreas Vegge, ${ }^{1}$ Majbritt R. Hufeldt, ${ }^{1}$ Mette T. Skaanild, ${ }^{1}$ Finn K. Vogensen, ${ }^{3}$ \\ Karsten Kristiansen, ${ }^{4}$ Axel K. Hansen, ${ }^{1}$ and John Nielsen ${ }^{5}$ \\ ${ }^{1}$ Department of Veterinary Disease Biology, Faculty of Health and Medical Sciences, University of Copenhagen, \\ 1870 Frederiksberg C, Denmark \\ ${ }^{2}$ Department of Chemistry, Faculty of Science, University of Copenhagen, 1870 Frederiksberg C, Denmark \\ ${ }^{3}$ Department of Food Science, Faculty of Science, University of Copenhagen, 1870 Frederiksberg C, Denmark \\ ${ }^{4}$ Department of Biology, Faculty of Science, University of Copenhagen, 2200 Copenhagen N, Denmark \\ ${ }^{5}$ Department of Drug Design and Pharmacology, Faculty of Health and Medical Sciences, University of Copenhagen, \\ 2100 Copenhagen $\emptyset$, Denmark
}

Correspondence should be addressed to Axel K. Hansen; akh@life.ku.dk

Received 2 January 2013; Revised 15 March 2013; Accepted 26 March 2013

Academic Editor: Kazim Husain

Copyright (C) 2013 Charlotte Andersen et al. This is an open access article distributed under the Creative Commons Attribution License, which permits unrestricted use, distribution, and reproduction in any medium, provided the original work is properly cited.

Consumption of isoflavones may prevent adiposity, hepatic steatosis, and dyslipidaemia. However, studies in the area are few and primarily with genistein. This study investigated the effects of formononetin and its synthetic analogue, 2-heptyl-formononetin (C7F), on lipid and cholesterol metabolism in C57BL/6J mice. The mice were fed a cholesterol-enriched diet for five weeks to induce hypercholesterolemia and were then fed either the cholesterol-enriched diet or the cholesterol-enriched diet-supplemented formononetin or C7F for three weeks. Body weight and composition, glucose homeostasis, and plasma lipids were compared. In another experiment, mice were fed the above diets for five weeks, and hepatic triglyceride accumulation and gene expression and histology of adipose tissue and liver were examined. Supplementation with C7F increased plasma HDL-cholesterol thereby increasing the plasma level of total cholesterol. Supplementation with formononetin did not affect plasma cholesterol but increased plasma triglycerides levels. Supplementation with formononetin and C7F induced hepatic steatosis. However, formononetin decreased markers of inflammation and liver injury. The development of hepatic steatosis was associated with deregulated expression of hepatic genes involved in lipid and lipoprotein metabolism. In conclusion, supplementation with formononetin and C7F to a cholesterol-enriched diet adversely affected lipid and lipoprotein metabolism in C57BL/6J mice.

\section{Introduction}

Over the last decade there has been a pronounced increase in the interest of the physiologic and pharmacologic effects of bioactive compounds. Of particular interest in relation to human health is a group of naturally occurring compounds called isoflavones which exhibit both hormonal and nonhormonal properties. These compounds are found in various legumes including soybean, green bean, and alfalfa sprout [1]. Originally isoflavones were studied for their effects on hormone-sensitive cancers, osteoporosis, menopause, and heart diseases [2]. However, recently the focus has been directed towards their effects on lipid metabolism. Data obtained from animal experiments as well as clinical and epidemiological studies suggest that consumption of isoflavones may prevent obesity [3, 4], type 2 diabetes [4], atherosclerosis [5], nonalcoholic fatty liver disease [6], and dyslipidaemia [7, 8]. Thus isoflavones might be useful in targeting the metabolic syndrome.

The most frequently studied isoflavone is genistein followed by daidzein. Supplementation with high doses of genistein or daidzein to rodents fed high-fat diets substantially 
decreases body weight and fat mass [9-11], lowers the plasma levels of total cholesterol, triglyceride, and LDL-cholesterol $[9,10,12,13]$, and protects against the development of hepatic steatosis $[9,10,14,15]$. Thus, supplementation with isoflavones or synthetic analogues could potentially be used in prevention and/or treatment of obesity, dyslipidaemia, and hepatic steatosis.

Formononetin is an $\mathrm{O}$-methylated isoflavone present in different bean types at various levels [16]. Previously extracts containing formononetin have been found to have an influence on fat metabolism $[17,18]$. However, as extract also contains a range of other compounds, it is difficult to make solid conclusions on the effects of formononetin based on these studies. One study also shows a cardioprotective effect of a derivative of formononetin [19], suggesting that formononetin and derivatives of formononetin could have a positive influence on obesity and related disorders. However, the effects of formononetin remain putative owing to the existence of a range of other compounds found in extracts.

A newly synthesised analogue of formononetin, 2-heptyl formononetin (C7F), affected lipid accumulation, lipolysis, and peroxisome proliferator-activated receptor $\gamma(\operatorname{PPAR} \gamma)$ activation in vitro more potently than synthetic formononetin (manuscript in preparation). Therefore, we aimed to investigate if formononetin and C7F positively affected lipid and cholesterol metabolism in C57BL/6 mice fed a cholesterolenriched diet by assessing the effect of formononetin and C7F on body weight and composition, glucose tolerance, plasma lipid composition, hepatic steatosis, and expression of genes involved in lipid metabolism and phase I and II metabolism.

\section{Materials and Methods}

\subsection{Synthesis of Compounds}

2.1.1. General Experimental Information. Commercially available reagents (Sigma-Aldrich, Germany) were used without further purification unless otherwise noted. Solvents used for the synthesis were of analytical grade, dried over activated $4 \AA$ molecular sieves when necessary (all solvents used under dry conditions had a water content of $<25 \mathrm{ppm}$ measured by coulometric Karl Fischer titration). Analytical thin layer chromatography was performed using precoated silica gel 60 F254 plates (Merck, Germany) and visualized using either UV light or potassium permanganate stain.

Column chromatography was performed on Merck Kiselgel $60(0.015-0.040 \mathrm{~mm})$ using the dry column vacuum chromatography (DCVC) technique [20]. High-performance liquid chromatography was performed on a Waters 2525 system equipped with a Waters 2996 photodiode array detector and a Waters 2767 Sample Manager using a $100 \mathrm{~mm} \times 19 \mathrm{~mm}$ i.d. XTerra prep MS C18 column (Waters Corp., MA, USA) with a gradient of acetonitrile in Milli-Q water with a flow of $15 \mathrm{~mL} / \mathrm{min}$ (Waters). Melting points were measured on a Reichert melting point microscope, model N254-1R (Austria). ${ }^{1} \mathrm{H}$ and ${ }^{13} \mathrm{C}$ NMR spectroscopic data were recorded on a Bruker Avance 300 (Bruker BioSpin MRI, Germany) using deuterated solvents as a lock. Chemical shifts are reported in parts per million relative to the residual solvent peak $\left({ }^{1} \mathrm{H} \mathrm{NMR}\right)$ or the solvent peak $\left({ }^{13} \mathrm{C} \mathrm{NMR}\right)$ as the internal standard. Accurate mass determinations were performed on a Micromass LCT apparatus (UK) equipped with an APESI probe calibrated with Leu-Enkephalin $(556.2771 \mathrm{~g} / \mathrm{mol})$. All spectrophotometric measurements were performed on a Shimadzu UV-2101PC UV-vis scanning spectrophotometer with automatic cell changer and a temperature-controlled water-jacket-regulated cell holder (Shimadzu Corp., Japan).

2.1.2. Synthesis of C7F. 2,4-Dihydroxy-4'-methoxy-deoxybenzoin $(2.5 \mathrm{~g}, 9.7 \mathrm{mmol})$ was dissolved in $50 \mathrm{~mL}$ of dry THF. The stirred solution was cooled to $0^{\circ} \mathrm{C}$, and triethylamine (4.1 mL, 3 eq.) was added. After $5 \mathrm{~min}$. octanoyl chloride (3.7 mL, 2.2 eq.) was added, and the cooling was stopped. After $15 \mathrm{~min}$. the reaction mixture was acidified with $50 \mathrm{~mL}$ of $1 \mathrm{M} \mathrm{HCl}$. The yellow solution was extracted twice with EtOAc, and the combined organic phases were washed with water, sat. $\mathrm{NaHCO}_{3}$ aq., and brine. After removal of the solvent, the resulting residue was dried in vacuo. Purification by dry column vacuum chromatography (EtOAc/Heptane on silica $-5 \%$ gradient) yielded the diester $(4.7 \mathrm{~g}, 95 \%)$.

${ }^{13} \mathrm{C}$ NMR $\left(75 \mathrm{MHz}, \mathrm{CDCl}_{3}\right): \delta=197.03,172.02,171.45$, $158.75,153.98,150.20,130.98,130.69,126.17,119.09,117.50$, $114.25,55.37,47.43,34.50,34.41,31.78,29.18,29.15,29.08,29.02$, 24.91, 24.65, 22.74, $14.20 \mathrm{ppm}$.

${ }^{1} \mathrm{H}$ NMR $\left(300 \mathrm{MHz}^{\mathrm{CDCl}}{ }_{3}\right) \delta=7.80(\mathrm{~d}, J=8.6 \mathrm{~Hz}, 1 \mathrm{H})$, $7.26(\mathrm{~s}, 1 \mathrm{H}), 7.12$ (d, $J=8.7 \mathrm{~Hz}, 2 \mathrm{H}), 7.06(\mathrm{dd}, J=8.6,2.2 \mathrm{~Hz}$, $1 \mathrm{H}), 6.94(\mathrm{~d}, J=2.2 \mathrm{~Hz}, 1 \mathrm{H}), 6.86(\mathrm{~d}, J=8.7 \mathrm{~Hz}, 2 \mathrm{H}), 4.11$ (s, $2 \mathrm{H}), 3.79$ (s, 3H), 3.82-3.75 (m, 4H), 1.80-1.62 (m, 4H), 1.47$1.18(\mathrm{~m}, 16 \mathrm{H}), 0.94-0.79(\mathrm{~m}, 6 \mathrm{H}) \mathrm{ppm}$.

2,4-Dihydroxy-4' -methoxy-deoxybenzoin (4.7 g, $9.2 \mathrm{mmol}$ ) was dissolved into $60 \mathrm{~mL}$ of anhydrous THF and DBU ( $1.6 \mathrm{~mL}, 1.1$ eq.) was added. The reaction mixture was heated to reflux for 1 hour, at which point $5 \mathrm{~mL}$ conc. $\mathrm{HCl}$ was added and the heating was continued for 1 hour. The reaction was monitored by TLC, and after complete conversion $\mathrm{NaOH}$ $(6 \mathrm{~mL}, 10 \mathrm{M})$ was added and the solution was refluxed for another $30 \mathrm{~min}$. The reaction was again monitored by TLC until complete conversion was observed. At this point, $1 \mathrm{M}$ $\mathrm{HCl}$ was added until the reaction mixture was neutralised. The yellow solution was cooled and extracted twice with EtOAc. The combined organic phases were washed with water, sat. $\mathrm{NaHCO}_{3}$ aq., and brine. After removal of solvent, the resulting residue was dried in vacuo. The residue was purified by dry column vacuum chromatography (EtOAc/ heptane on silica $5 \%$ gradient) yielding C7F (2.63 g, 78\%) as a white foam.

${ }^{13} \mathrm{C} \mathrm{NMR}\left(75 \mathrm{MHz}, \mathrm{CDCl}_{3}\right) \delta=177.82,168.02,162.83$, $159.37,158.17,131.72,127.68,125.02,122.37,115.73,114.13,102.77$, $77.58,77.16,76.74,55.36,32.73,31.73,29.24,28.95,27.62,22.72$, $14.18 \mathrm{ppm}$.

${ }^{1} \mathrm{H}$ NMR $\left(300 \mathrm{MHz}, \mathrm{CDCl}_{3}\right) \delta=8.02(\mathrm{~d}, J=8.7 \mathrm{~Hz}, 1 \mathrm{H})$, 7.89-7.40 (bs), 7.15 (d, $J=8.7 \mathrm{~Hz}, 2 \mathrm{H}), 6.91$ (d, $J=8.7 \mathrm{~Hz}, 2 \mathrm{H})$, 6.88-6.83 (m, 2H), $3.78(\mathrm{~s}, 3 \mathrm{H}), 2.58-2.49(\mathrm{~m}, 2 \mathrm{H}), 1.75-1.55$ (m, 2H), 1.36-1.10 (m, 8H), 0.94-0.76 (m, 3H) ppm. 


\subsection{Mouse Study}

2.2.1. Preparation of Experimental Diets. The basic diet used for preparation of the experimental diets was C1000 (Altromin, Germany), a standard maintenance rodent diet free of phytoestrogens and with all polysaccharides derived from corn starch. Three experimental diets were prepared; a diet enriched with $2 \%$ cholesterol, a diet enriched with $2 \%$ cholesterol and $1000 \mathrm{mg} / \mathrm{kg}$ formononetin $(3.7 \mathrm{mmol} / \mathrm{kg})$, and a diet enriched with $2 \%$ cholesterol and $1300 \mathrm{mg} / \mathrm{kg}$ C7F $(3.6 \mathrm{mmol} / \mathrm{kg})$. For pelleting $2 \%$ gelatin, $0.5 \%$ magnesiumstearate and $5 \%$ talcum were added to the diets. For composition of the diet See Supplementary Table 1 in Supplementary material available online at http://dx.doi.org/10.1155/2013/ 926942.

2.2.2. Animals and Study Design. All animal studies were performed in accordance with the Council of Europe Convention ETS 123, in which the principles are equivalent to the PHS Policy on Humane Care and Use of Laboratory Animals. The study was approved by the Danish Animal Experimentation Inspectorate (License no. 2007-561-1434). All mice were housed in type III makrolon cages (Tecniplast, Italy) with aspen bedding and environmental enrichment (Tapvei Oy, Finland). All mice were housed under environmentally controlled conditions with an alternating 12-hour light: dark cycle with access to food and water ad libitum except when food was withheld for the experimental protocols described in the following. Food and water were changed several times weekly. C57BL/6JBomTac mice, purchased from Taconic (Denmark), were selected for the study as it is one of the mostly used mouse strains within this field due to its susceptibility to diet-induced obesity, type 2 diabetes, and low-grade inflammation [21]. The mice were approximately four weeks old when recruited to the study as we wanted to study the effects in early life as obesity problems are often established when growing up.

Experiment 1. 126 male mice were housed in groups of five mice. The mice were randomly divided into five groups and allowed one week of acclimatisation where they were fed the cholesterol-free $\mathrm{C} 1000$ diet. After this period, one group ( $n=30)$ was euthanized and the remaining mice were fed the cholesterol diet for five weeks to induce hypercholesterolemia. After this period, another group $(n=23)$ was euthanized and the remaining mice were fed the experimental diets (cholesterol $(n=25)$, formononetin $(n=23)$, or C7F $(n=25)$ ) for additionally three weeks before they were euthanized. The group size was calculated based upon serum cholesterol levels from a previous study on isoflavones in mice [22], in which a difference in relation to isoflavone feeding was approximately $5 \%$ with a standard deviation of approximately $6 \%$. Thus a power calculation setting the power to 0.9 showed that a difference could be shown with 25 mice and $P<0.01$. Body weight was measured weekly during the entire period.

Experiment 2. 32 male mice were housed in groups of four mice. The mice were randomly divided into four groups $(n=8)$ and allowed one week of acclimatisation where they were fed the cholesterol-free $\mathrm{C} 1000$ diet. The group size was calculated on the basis of a previous study on gene expression in relation to daidzein feeding [9], in which the relevant gene expressions were at least $50 \%$ different between the groups, and no standard deviation was more than $25 \%$. Thus a power calculation setting the power to 0.9 showed that a difference could be shown with 8 mice and $P<0.01$. One group was fed the cholesterol-free $\mathrm{C} 1000$ diet (chow) for the whole experiment. The other three groups were fed the cholesterolenriched diet for five weeks before initiation of experimental period with feeding of cholesterol, formononetin, or C7F for additionally five weeks. Body weight and food intake were measured weekly during the entire period.

For termination of both studies, the mice were deprived of food for 12 hours. The mice were anesthetised with a mixture of Hypnorm (Vetapharma, UK) and Dormicum (Roche, Denmark) as previously described [23]. After loss of reflexes, blood was collected from the retroorbital sinus into heparinised tubes, and the mice were euthanized by cervical dislocation. In experiment 1 , the livers were removed, and a slice from each liver was transferred to RNA later and kept at $-20^{\circ} \mathrm{C}$. Caecum samples were collected aseptically and immediately frozen at $-80^{\circ} \mathrm{C}$ until use. In experiment 2 , white adipose tissues (WAT) (inguinal WAT (iWAT), epididymal WAT (eWAT), intrascapular brown adipose tissue (iBAT), and liver were dissected, and half was freeze clamped and frozen at $-80^{\circ} \mathrm{C}$ and the other half was fixed in $4 \%$ paraformaldehyde in phosphate buffer and later dehydrated and embedded in paraffin.

2.3. Oral Glucose Tolerance Test. An oral glucose tolerance test was performed in experiment 1 prior to the initiation of the experimental diets and again at termination of the experimental period. The mice were fasted overnight, blood was collected from the tail vein as previously described [24] at time points $-30,0,30,60,120$, and 180 minutes, and glucose was monitored immediately on a FreeStyle Mini glucometer (Hermedico, Denmark) as previously described [25]. After the first two blood samples at $t=0$, each mouse was dosed p.o. with $2 \mathrm{~g} / \mathrm{kg}$ glucose $(500 \mathrm{~g} / \mathrm{L}$ Glucose SAD infusion solution, Veterinary Pharmacy, University of Copenhagen, Denmark).

2.4. DXA Scan. Prior to euthanasia in experiment 1, Dual Energy X-ray Absorptiometry (DXA) scan (GE Lunar Prodigy, General Electric, WI, USA) was performed with the scanner running the small animal software from the same manufacturer. The anesthetised mice were placed at specific marks on a piece of carton to make sure that all animals were similarly arranged in the scanner. The carton alone was evaluated prior to the first scan with a satisfying result (no measureable values). Body weight, body fat percentage, fat mass, bone mineral content, and bone mineral density were determined.

2.5. Blood Sampling and Analysis of Plasma Lipids. Plasma was harvested after centrifugation at $3000 \mathrm{~g}$ at room 
temperature for $10 \mathrm{~min}$ and stored at $-80^{\circ} \mathrm{C}$ until analysed. From experiment 1, total plasma cholesterol, HDLcholesterol, LDL-cholesterol, and triglycerides were measured enzymatically and photometrically on ABXPentra400 (Horiba Group, France) using $120 \mu \mathrm{L}$ of plasma. From experiment 2, plasma levels of alanine transaminase (ALT) and aspartate transaminase (AST) were analysed using Biovision kits (AH Diagnostics, Denmark). Samples were run in duplicates for all analyses.

\subsection{Gene Expression}

Samples from Experiment 1. Total RNA was isolated from liver slices using the Nucleospin Kit (Macherey Nagel, Germany) according to manufacturer's protocol. The quality of the RNA was assessed (all 260/280 > 2 and all 260/230 > 1.7). The reverse transcription and PCR were set up using $\mathrm{RT}^{2}$ Firststrand Kit and $\mathrm{RT}^{2}$ SYBR Green qPCR Master Mix from SABiosciences (Tebu-bio, Denmark). The reactions were set up according to the Kit manuals. The gene expression analysis was carried out using Mouse Drug Metabolism array plates from SA Biosciences. Three array plates were set up for each group of animals (seven animals per plate). For each array, $1.5 \mu \mathrm{g}$ total RNA was used, $0.21 \mu \mathrm{g}$ of total RNA from each animal. In the mouse drug metabolism array, gene expression of 84 genes involved mainly in phase I and phase II metabolism can be analysed (Supplementary Table 2). The array also includes negative and positive control and the following 5 housekeeping genes: $\beta$-glucuronidase, hypoxanthine guanine phosphoribosyl transferase 1 , heat shock protein $90 \alpha$, glyceraldehyde-3-phosphate dehydrogenase, and $\beta$-actin in order to calculate expression changes.

Samples from Experiment 2. Total RNA was purified from eWAT, iWAT, iBAT, and liver using Trizol (Invitrogen, Denmark) and RNA concentration was measured on a Nanodrop (Thermo Scientific, Denmark). cDNA was synthesised with RevertAid (Fermentas, Germany) according to manufacturer's instructions. Reactions were diluted with $120 \mu \mathrm{L}$ of water and frozen at $-80^{\circ} \mathrm{C}$ until analysed on Roche LightCycler 480 (Roche). cDNA was analysed in duplicates in $20 \mu \mathrm{L}$ reactions containing SYBR Green Mastermix (Roche), $3 \mu \mathrm{L}$ of diluted $\mathrm{cDNA}$, and $300 \mathrm{nM}$ of each primer. Reaction mixtures were denaturated at $95^{\circ} \mathrm{C}$ for $2 \mathrm{~min}$ followed by 40 cycles of $95^{\circ} \mathrm{C} / 15 \mathrm{~s}, 60^{\circ} \mathrm{C} / 15 \mathrm{~s}, 72^{\circ} \mathrm{C} / 20 \mathrm{~s}$. Data was analysed using Roche Lightcycler software and the $\Delta \Delta \mathrm{Ct}$ method and normalised to $18 \mathrm{~S}$ ribosomal RNA. Primers for RTPCR were purchased from TAG Copenhagen (Denmark) (Supplementary Table 3).

2.7. Gut Microbiota Composition Analysis. DNA was extracted from the ceacum samples from Experiment 1 using the QIAamp DNA Stool Mini Kit (Qiagen, Germany) according to the manufacturer's instructions and stored at $-40^{\circ} \mathrm{C}$ until analysis during which the $\mathrm{V} 3$ region of the $16 \mathrm{~S}$ rRNA gene was amplified by PCR using the following universal primer set PRBA338f and PRUN518r (5'-C GCC CGC CGC GCG CGG CGG GCG GGG CGG GGG CAC GGG GGG ACT CCT ACG GGA GGC AGC AG-3' and $5^{\prime}$-ATT ACC GCG
GCT GCT GG-3') [26] (Eurofins MWG Operon, Germany). All reactions were carried out in a $50 \mu \mathrm{L}$ volume containing 1.25 U HotMaster Taq DNA Polymerase (5 Prime, Germany), $5 \mu \mathrm{L} 10 \times$ HotMaster Taq Buffer with $2.5 \mathrm{mM} \mathrm{MgCl}_{2} \quad(5$ Prime), $100 \mathrm{ng}$ DNA, $10 \mathrm{pmol}$ of each primer, $0.3 \mathrm{mM}$ dNTP (Bioline, Germany), and $1 \mu \mathrm{g}$ BSA (Sigma-Aldrich). The PCR reaction was performed on a Robocycler Thermoblock (Stratagene, Denmark). Initial denaturation was done at $95^{\circ} \mathrm{C}$ for 5 minutes, and amplification was carried out using 30 cycles each including denaturation at $95^{\circ} \mathrm{C}$ for 30 seconds, annealing at $60^{\circ} \mathrm{C}$ for 30 seconds, and extension at $72^{\circ} \mathrm{C}$ for 40 seconds, followed by a final elongation step at $72^{\circ} \mathrm{C}$ for 10 minutes. A final product length of approximately $230 \mathrm{bp}$ was checked by electrophoresis on a $2 \%$ agarose gel, stained with Ethidium Bromide (Bio-Rad, CA, USA). PCR amplicons were analysed by DGGE using the INGENYphorU-2 system according to the manufacturer's instructions (INGENY, The Netherlands). The acrylamide concentration in the gel was $9 \%$ and the linear denaturation gradient was $30 \%$ to $65 \%$ (100\% denaturant corresponds to $7 \mathrm{M}$ urea and $40 \%$ deionized formamide). Before loading, $35 \mu \mathrm{L}$ PCR product was mixed with $6 \mu \mathrm{L} 6 \times$ loading dye. In addition to the samples analysed, an in-house standard PCR product was loaded, allowing accurate alignment of lanes and bands within and between gels. Electrophoresis was performed in $0.5 \times$ TAE $(1 \times$ TAE corresponds to $40 \mathrm{mM}$ Tris-acetate, $1 \mathrm{mM}$ EDTA, $\mathrm{pH}$ 8.0 ), at $60^{\circ} \mathrm{C}$ for 16 hours at 120 Volt. Staining was performed with a 1:10000 SYBR Gold staining solution (Invitrogen, OR, USA) in $1 \times$ TAE for 1 hour and photographed with UV transillumination (302 nm) using a Kodak EDAS 290 system (Eastman Kodak).

2.8. Histology. From Experiment 2, sections of paraffinembedded adipose tissue and liver were cut into $3 \mu \mathrm{m}$ thick slices and stained with haematoxylin and eosin according to standard procedures.

2.9. Triglyceride Measurements. From Experiment 2, total lipids were extracted from the liver using a modified version of the Bligh and Dyer protocol. In brief, $25 \mathrm{mg}$ tissues was homogenised in potassium phosphate buffer, and lipids were extracted with chloroform:methanol $(1: 2)$. $\mathrm{HCl}$ was added, and the chloroform phase transferred to new tubes and evaporated under nitrogen. The extract was dissolved in LPL buffer (28.75 mM PIPES, $57.41 \mathrm{mM} \mathrm{MgCl}_{2} \cdot 6 \mathrm{H}_{2} \mathrm{O}$, $0.569 \mathrm{mg} / \mathrm{mL}$ BSA-FFA, $0.1 \%$ SDS) and analysed with a triglyceride kit (Zen-Bio, NC, USA).

2.10. Statistics. Area under curve (AUC) was calculated from weighing and data from the oral glucose tolerance test. Three-dimensional principal component analysis (3D-PCA) based on DGGE data was carried out (Applied Maths). All quantitative data were tested for normality by AndersonDarling test, compared in a general linear model with the settings group cage (group), and finally significant differences between groups were further evaluated comparing individual groups by an unpaired two-sample $t$-test. Software developed by SABiosciences (Tebu-bio) specifically for gene 
TABLE 1: Body composition as shown by DXA scans of C57BL/6 mice before cholesterol feeding, after five weeks of initial cholesterol feeding and after three additional weeks where the mice were fed the cholesterol-enriched diet supplemented with either formononetin or 2-heptylformonetin (C7F) (Experiment 1). Data show mean \pm SEM. Different letters ( $a, b, c)$ denote significant difference between the groups.

\begin{tabular}{lccccc}
\hline & Fat percentage & $\begin{array}{c}\text { Body weight } \\
(\mathrm{g})\end{array}$ & $\begin{array}{c}\text { Fat mass } \\
(\mathrm{g})\end{array}$ & $\begin{array}{c}\text { Bone mineral } \\
\text { concentration } \\
(\mathrm{g})\end{array}$ & $\begin{array}{c}\text { Bone mineral density } \\
\left(\mathrm{mg} / \mathrm{cm}^{3}\right)\end{array}$ \\
\hline \multicolumn{5}{c}{ Before test period } \\
\hline After acclimatisation $(n=30)$ & $19.3 \pm 7.8^{\mathrm{a}}$ & $16.7 \pm 2.0^{\mathrm{a}}$ & $3.2 \pm 1.8$ & $0.3 \pm 0.1^{\mathrm{ab}}$ & $640 \pm 9^{\mathrm{a}}$ \\
After initial cholesterol feeding $(n=23)$ & $13.7 \pm 6.8^{\mathrm{b}}$ & $24.3 \pm 1.3^{\mathrm{b}}$ & $3.2 \pm 1.7$ & $0.3 \pm 0.1^{\mathrm{a}}$ & $802 \pm 10^{\mathrm{b}}$ \\
\hline \multicolumn{5}{c}{ After test period } \\
\hline Cholesterol $(n=25)$ & $14.8 \pm 8.2^{\mathrm{b}}$ & $28.0 \pm 2.1^{\mathrm{c}}$ & $4.2 \pm 2.6$ & $0.4 \pm 0.07^{\mathrm{b}}$ & $864 \pm 6^{\mathrm{c}}$ \\
Cholesterol + formononetin $(n=23)$ & $13.1 \pm 9.6^{\mathrm{b}}$ & $27.8 \pm 2.3^{\mathrm{abc}}$ & $3.6 \pm 2.8$ & $0.4 \pm 0.11^{\mathrm{bb}}$ & $839 \pm 9^{\mathrm{bc}}$ \\
Cholesterol $+\operatorname{C7F}(n=24)$ & $14.5 \pm 5.5^{\mathrm{b}}$ & $26.1 \pm 2.2^{\mathrm{d}}$ & $3.2 \pm 1.7$ & $0.4 \pm 0.08^{\mathrm{ab}}$ & $825 \pm 10^{\mathrm{bc}}$ \\
\hline
\end{tabular}

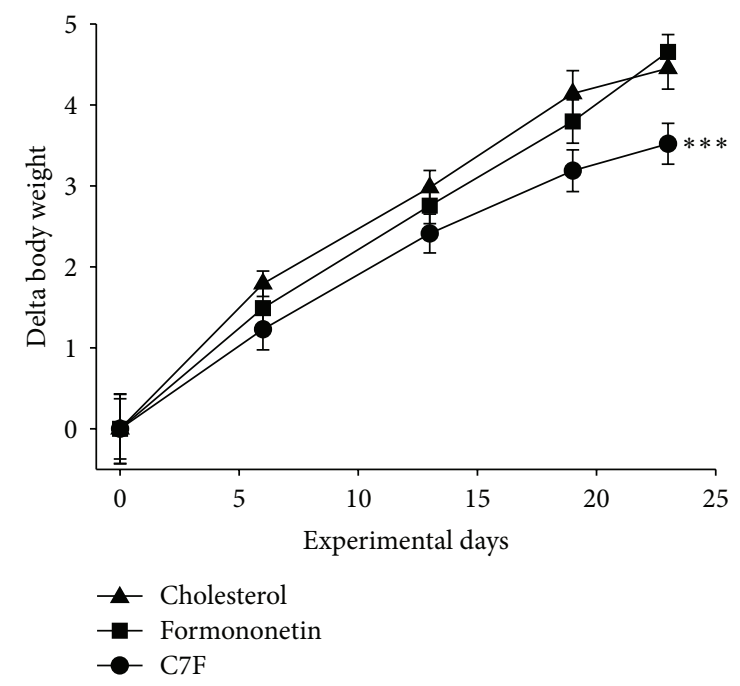

Figure 1: Body weight of cholesterol fed C57BL/6 mice $(n=23-$ 25) supplemented with either formononetin or 2-heptyl-formonetin (C7F) for three weeks (Experiment 1). Graphs show mean \pm SEM. ${ }^{*} P \leq 0.05$.

expression arrays was used to calculate the fold changes in gene expression for gene expression and $P$ values in Experiment 1. In Experiment 1, all ANOVAs were performed by the software Minitab ver. 14 (Minitab, PA, USA). In Experiment 2, differences between the groups were analysed using the GLM procedure in SAS (SAS 9.3, SAS Institute). Data were considered statistically significant when $P \leq 0.05$.

\section{Results}

3.1. Supplementation with C7F Decreased Body Weight Gain. At the end of Experiment 1, mice fed cholesterol plus C7F weighed significantly less than the mice fed only cholesterol $(P<0.05)$. There were no weight differences between the mice fed only cholesterol and those fed cholesterol plus formononetin (Figure 1). The fat percentage was decreased in all three experimental groups after cholesterol feeding and after the experimental period compared to the initial acclimatisation period. However, there were no differences among the three experimental groups (Table 1). Bone mineral concentration and bone mineral density increased significantly from the initial acclimatisation period over the cholesterol induction period till the experimental period, but there were no differences among the experimental groups (Table 1).

Difference in weight development can be due to differences in gut microbiota [27]. However, even though there was a significant clustering in gut microbiota composition in relation to feeding on the $y$ - and $z$-axis of the PCA-plot this was mainly due to caging (Supplementary Figure 1).

3.2. The Cholesterol-Enriched Diet Increased Plasma Levels of Total Cholesterol and HDL-Cholesterol and Decreased Plasma Levels of Triglycerides. The cholesterol-enriched diet was expected to elevate the plasma level of cholesterol. However, although total plasma cholesterol increased after the first five weeks of cholesterol feeding, the difference was not significant. Yet, after the experimental period, the plasma level of total cholesterol was significantly higher for mice fed cholesterol compared to the mice euthanized before initiation of cholesterol feeding. Surprisingly, the plasma level of HDL-cholesterol was significantly increased, and the plasma level of triglycerides was decreased in mice fed cholesterol compared to mice euthanized before initiation of cholesterol feeding. Cholesterol feeding did not affect LDLcholesterol (Table 2).

3.3. Supplementation with C7F Increased Plasma Cholesterol. Mice fed C7F had significantly higher plasma levels of total cholesterol and HDL-cholesterol than mice fed cholesterol or formononetin. Furthermore, mice fed formononetin had increased plasma level of triglycerides compared to mice fed cholesterol. There were no differences between the experimental groups with respect to LDL-cholesterol (Table 2).

3.4. Formononetin and C7F Did Not Affect Glucose Tolerance. Isoflavones have been reported to improve glucose uptake in vitro and glucose tolerance in vivo $[28,29]$. However, mice fed cholesterol diet supplemented with either formononetin or C7F did not differ in glucose tolerance as monitored by an oral glucose tolerance test (Figure 2(a)) or in fasting glucose 
TABLE 2: Plasma lipid profiles of C57BL/6 mice before cholesterol feeding, after five weeks of initial cholesterol feeding and after three additional weeks where the mice were fed the cholesterol-enriched diet supplemented with either formononetin or 2-heptyl-formonetin (C7F) (Experiment 1). Data show mean \pm SEM. Different letters ( $a, b, c, d)$ denote significant difference $(P \leq 0.05)$ between the groups.

\begin{tabular}{|c|c|c|c|c|}
\hline & Total cholesterol $(\mathrm{mmol} / \mathrm{L})$ & $\mathrm{HDL}(\mathrm{mmol} / \mathrm{L})$ & $\mathrm{LDL}(\mathrm{mmol} / \mathrm{L})$ & Triglycerides $(\mathrm{mmol} / \mathrm{L})$ \\
\hline \multicolumn{5}{|c|}{ Before test period } \\
\hline After acclimatisation $(n=30)$ & $3.12 \pm 0.20^{\mathrm{a}}$ & $1.39 \pm 0.10^{\mathrm{a}}$ & $0.32 \pm 0.05$ & $1.95 \pm 0.55^{\mathrm{a}}$ \\
\hline After initial cholesterol feeding $(n=23)$ & $3.22 \pm 0.26^{\mathrm{ab}}$ & $1.40 \pm 0.11^{\mathrm{ab}}$ & $0.35 \pm 0.07$ & $1.13 \pm 0.30^{\mathrm{ab}}$ \\
\hline \multicolumn{5}{|c|}{ After test period } \\
\hline Cholesterol $(n=25)$ & $3.32 \pm 0.25^{\mathrm{bc}}$ & $1.46 \pm 0.15^{\mathrm{b}}$ & $0.29 \pm 0.06$ & $0.95 \pm 0.27^{\mathrm{c}}$ \\
\hline Cholesterol + formononetin $(n=23)$ & $3.43 \pm 0.27^{\mathrm{c}}$ & $1.44 \pm 0.16^{\mathrm{ab}}$ & $0.34 \pm 0.14$ & $1.16 \pm 0.29^{\mathrm{b}}$ \\
\hline Cholesterol + C7F $(n=25)$ & $3.83 \pm 0.54^{\mathrm{d}}$ & $1.78 \pm 0.18^{\mathrm{c}}$ & $0.28 \pm 0.10$ & $1.03 \pm 0.39^{\mathrm{bc}}$ \\
\hline
\end{tabular}

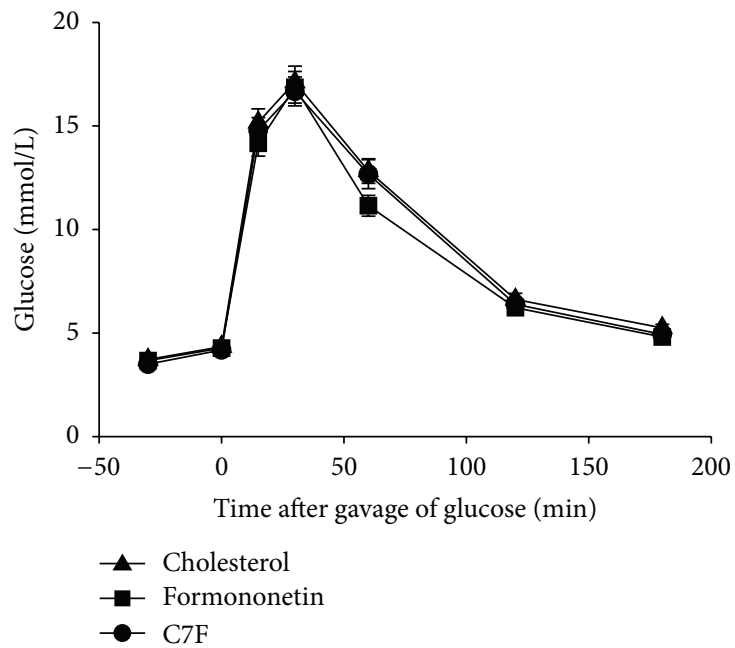

(a)

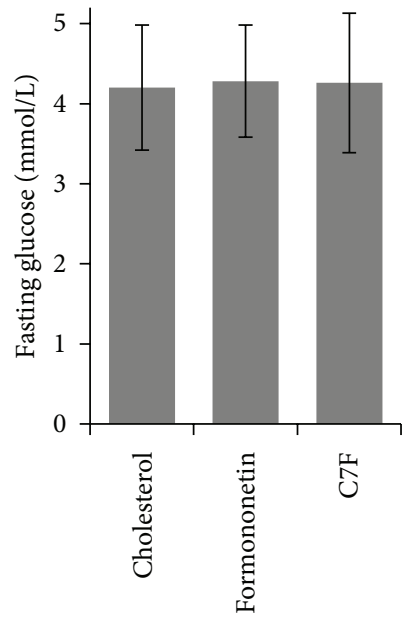

(b)

Figure 2: Glucose homeostasis of cholesterol fed C57BL/6 mice $(n=23-25)$ supplemented with either formononetin or 2-heptylformononetin (C7F) for three weeks (Experiment 1). (a) Glucose clearance assessed by oral glucose tolerance test ( $2 \mathrm{~g} / \mathrm{kg}$ glucose). (b) Fasting plasma glucose concentration. Graphs show mean \pm SEM.

levels (Figure 2(b)) (Experiment 1) compared to control mice fed only the cholesterol diet.

3.5. C7F Upregulated the Expression of Gstm1. Isoflavones have been shown to affect phase I and II metabolism of drugs in the liver [30]. Scatter plots of the liver gene expression in Experiment 1 showed that Gstm1 (glutathione S-transferase Mu 1) was significantly upregulated 2.4 times in mice fed cholesterol plus C7F compared to those fed only cholesterol. Furthermore, the expression of Cyp11b2 (aldosterone synthase) was 12.9 times upregulated in mice fed C7F compared to formononetin (Supplementary Figure 2).

3.6. Formononetin and C7F Induced Hepatic Steatosis. To further asses the effects of formononetin and C7F on lipid metabolism in liver and adipose tissues, a second experiment was carried out. There were no significant differences in weight development in this study perhaps because of the lower number of mice in each group (Supplementary Figure 3). Feed intake was measured weekly but showed no differences between the groups (Supplementary Figure 4).
It is well-documented that genistein and daidzein protect against the development of hepatic steatosis in rodents fed high-fat diets $[9,10,14,15]$. At termination of Experiment 2 weight of the liver was significantly increased in the mice fed cholesterol compared to the other groups. The liver weight was similar for chow and C7F fed mice but increased for mice fed formononetin (Figure 3(A)). Quantification of triglycerides in the liver showed no difference between mice fed chow and cholesterol. In contrast, there was a large increase in hepatic accumulation of triglycerides in the mice fed formononetin and C7F (Figure 3(B)). The development of hepatic steatosis was confirmed by visual examination of $\mathrm{H} \& \mathrm{E}$ stained sections of the livers (Experiment 2) revealing clear microvesicular structures presumably from fat vacuoles in mice fed C7F and formononetin (Figure 3(C)).

3.7. Formononetin Protected against Hepatic Inflammation and Dysfunction. The development of hepatic steatosis is often associated with hepatic inflammation and/or liver injury. Surprisingly, the expression of Tnf (tumour necrosis factors $\alpha$ ) was similar in mice fed chow, cholesterol, and C7F but decreased in mice fed formononetin (Figure 3(D)), 


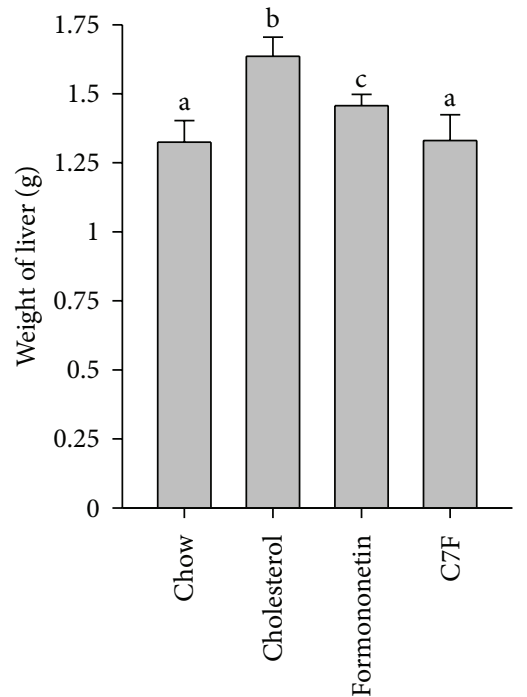

(A)
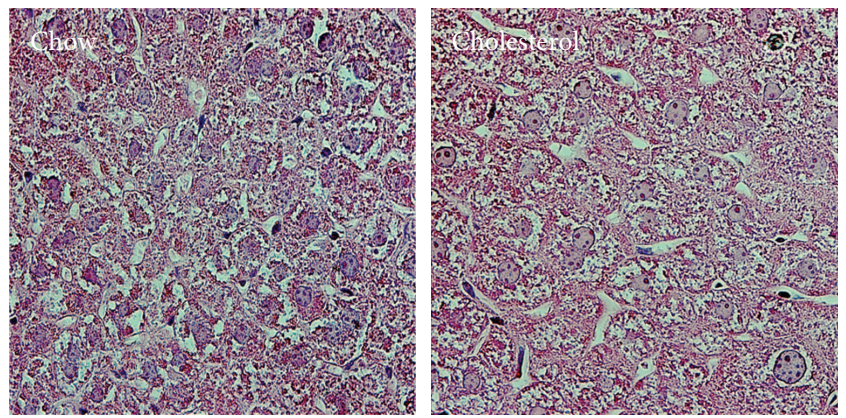

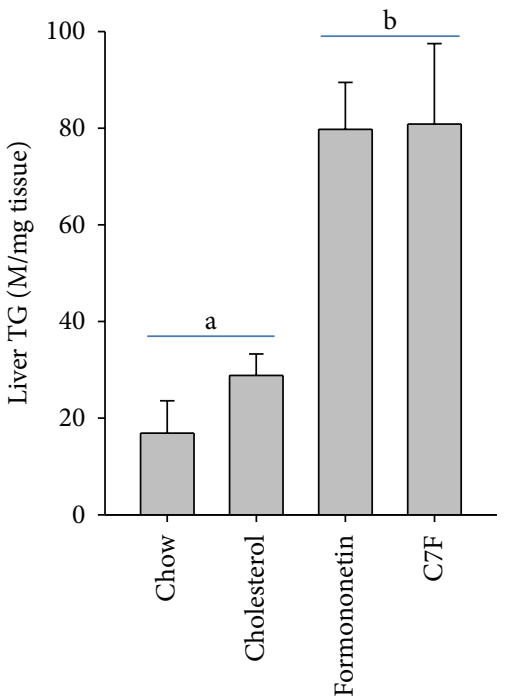

(B)


(C)

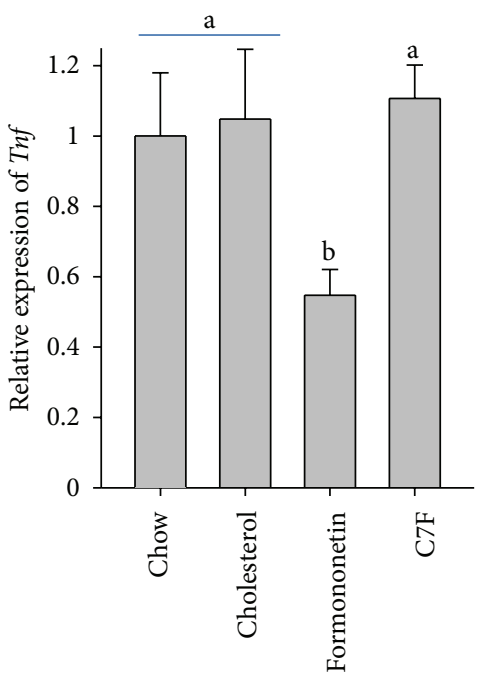

(D)
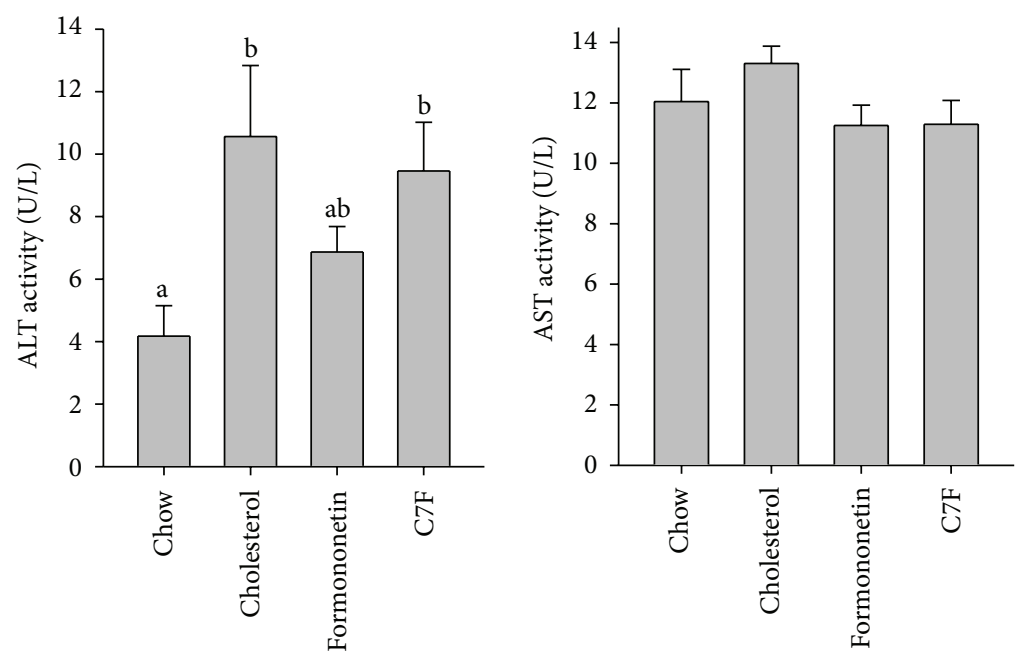

(E)

FIGURE 3: Development of hepatic steatosis in C57BL/6 mice fed chow, cholesterol, or cholesterol supplemented with formononetin or 2heptyl-formonetin (C7F) for five weeks (Experiment 2). (A) Weight of liver $(n=8)$. (B) Triglyceride content in liver $(n=6)$. Total lipids were extracted from liver using a modified version of the Bligh and Dyer protocol, and the content of triglyceride were analysed with a commercial kit. (C) Liver sections stained with hematoxylin and eosin. (D) Hepatic gene expression of Tnf (tumour necrosis factor $\alpha$ ) measured by RTPCR. Data is normalised to $18 \mathrm{~S}$ ribosomal RNA and presented relatively to the expression in chow $(n=6)$. (E) Plasma level of aspartate aminotransferase (AST) and alanine aminotransferase (ALT) $(n=6)$. Graphs show mean \pm SEM. Different letters $(\mathrm{a}, \mathrm{b})$ denote significant difference $(P \leq 0.05)$ between the groups. 
suggesting less hepatic inflammation in formononetin fed mice. Similarly, the plasma level of ALT was increased in mice fed cholesterol and C7F compared to mice fed chow, whereas there was no increase for mice fed formononetin (Figure 3(E)). This indicates increased damage to the hepatocytes in mice fed cholesterol and C7F but not in mice fed formononetin. There was no difference in the plasma level of AST (Figure 3(E)).

3.8. Formononetin and C7F Decreased Lipogenesis, $\beta$-Oxidation, and Lipoprotein Metabolism. To investigate possible routes by which formononetin and C7F might induce hepatic steatosis, we measured hepatic expression of genes involved in lipogenesis, $\beta$-oxidation, and lipoprotein metabolism (Experiment 2).

Surprisingly the expressions of Acaca (acyl-CoA carboxylase-1) and Fasn (fatty acid synthase), the rate-limiting genes in lipogenesis, were significantly upregulated in cholesterol fed mice compared to chow but similar to chow for mice fed formononetin and C7F. The pattern was the same for Scd1 (stearoyl-CoA desaturase), the rate-limiting gene in the synthesis of monounsaturated fatty acids, although the expression was increased in formononetin compared to chow but not as much as in cholesterol-fed mice. There were no differences in the expressions of the lipogenic transcription factors Srebf1 (sterol regulatory element-binding protein-1c) and Mlxipl (MLX interacting protein-like or carbohydrate response element binding protein). The genes Gpam (glycerol phosphate acyltransferase) and Dgat2 (diglyceride acyltransferase 2) are both central to the synthesis of triglycerides. Compared to chow-fed mice, the expression of Gpam was upregulated in mice fed cholesterol but similar in mice fed formononetin and C7F. There was no difference between the groups for the expression of Dpat2 (Figure 4(A)).

Compared to mice fed chow, the expression of the lipolytic gene Atgl (adipose triglyceride lipase) was upregulated in mice fed cholesterol and C7F but not affected in mice fed formononetin. There was no difference in the expression of Ppara (peroxisome proliferator-activated receptor $\alpha$ ), a transcription factor involved in catabolism of fatty acids. The expression of Acoxl (acyl-CoA oxidase), involved in peroxisomal $\beta$-oxidation, was upregulated in cholesterol fed mice compared to the three other groups whereas the expression of Cptla (carnitine palmitoyl-CoA transferase-1a), involved in mitochondrial $\beta$-oxidation, was the same in all three groups compared to chow, although the expression was decreased in mice fed formononetin compared to cholesterol (Figure 4(B)).

The expression of Acat2 (acetyl-CoA acetyltransferase 2), responsible for synthesis of cholesteryl esters, was similar for mice fed cholesterol and chow but downregulated in mice fed formononetin and C7F. The expressions of Mttp (microsomal triglyceride transfer protein), which controls the assembly of lipoproteins, and Ldlr (low-density lipoprotein receptor), which mediates endocytosis of ApoB-containing lipoproteins, were both increased in mice fed cholesterol compared to chow but similar chow-fed mice and mice fed formononetin and C7F (Figure 4(C)).
As the mice were fed a cholesterol-enriched diet, it seemed likely that the metabolism of cholesterol could be affected. However, there was no difference in the level of genes central in cholesterol metabolism (Hmgcr (3-hydroxy-3methylglutaryl-Coenzyme A reductase), Cyp7a1 (cholesterol 7 alpha-hydroxylase), Nr1h3 (liver X receptor $\alpha$ ), and NrIh4 (farnesoid X receptor)) (Figure 4(D)).

3.9. C7F Increased Lipogenic and Lipolytic Gene Expression in $i W A T$. We also examined gene expression in the adipose tissues (Experiment 2). Of interest, the expressions of Srebf1 and Pparg (PPAR $\gamma$ ), master regulators of lipogenesis, were upregulated in eWAT in mice fed cholesterol and $\mathrm{C} 7 \mathrm{~F}$ compared to mice on chow (Figure 5(A)). Furthermore, the expressions of Srebf1, Acaca, Fasn, and Scd1 as well as Atgl were upregulated in iWAT from mice fed C7F compared to the three other groups (Figure 5(B)). The expression of Ucp1 (uncoupling protein-1), essential for nonshivering thermogenesis, was upregulated in iBAT from cholesterol-fed mice compared to the three other groups and in iWAT from mice fed C7F compared to the three other groups (Figures 5(B), and 5(C)). Also of interest, the expression of Emr1 (EGFlike module containing, mucin-like, hormone receptor-like sequence 1 or F4/80), a macrophage marker, was increased in eWAT from mice fed cholesterol and C7F, but compared to cholesterol-fed mice the expression was down-regulated in both eWAT and iWAT in mice fed formononetin (Figures 5(A) and 5(B)).

Visual examination of H\&E stained sections of eWAT, iWAT, and iBAT showed no differences in size of the adipocytes between the groups (data not shown) (Experiment 2).

\section{Discussion}

Supplementation with formononetin or C7F to C57BL/6J mice fed a cholesterol-enriched diet had limited effects on body weight, body composition, and glucose tolerance. However, C7F increased the serum level of total cholesterol and HDL-cholesterol. More importantly, formononetin and C7F induced hepatic steatosis by affecting adipocyte and hepatic gene expression, although hepatic gene expression of Tnf was decreased by formononetin.

Studies with genistein and daidzein using doses comparable to this study show a substantial decrease in body weight and fat mass [9-11] and improved glucose tolerance [28]. However, genistein and daidzein have been supplemented to mice fed high-fat diets and thus getting considerably obese which could explain contradictory results in the present study.

Surprisingly, formononetin and C7F induced hepatic steatosis. Increased lipogenesis and/or decreased $\beta$-oxidation promote the development of hepatic steatosis [31]. Hepatic gene expression suggested decreased peroxisomal $\beta$ oxidation but also decreased lipogenesis and decreased triglyceride assembly in mice fed formononetin and $\mathrm{C} 7 \mathrm{~F}$ compared to cholesterol suggesting overall decreased hepatic lipid metabolism. In mice fed formononetin, the expression of Acoxl was slightly decreased, correlating with decreased 


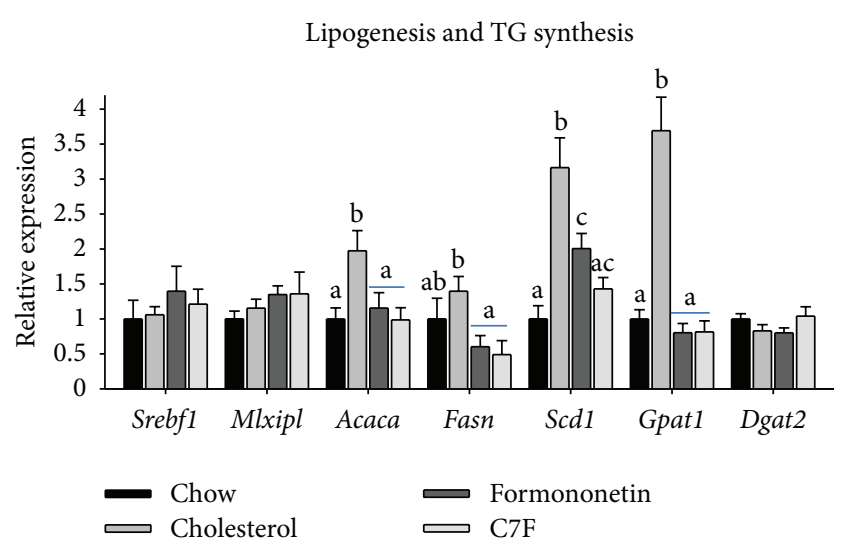

(A)

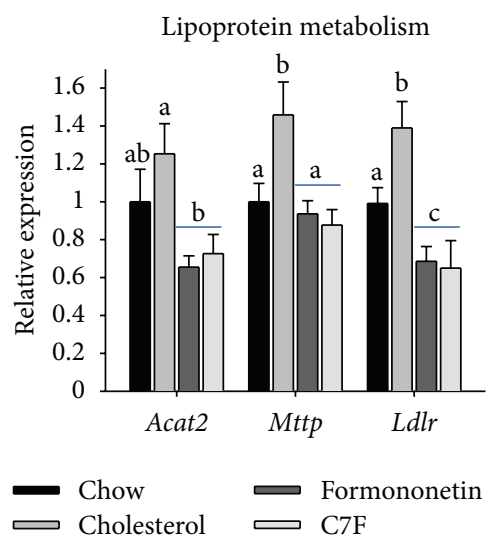

(C)



(B)

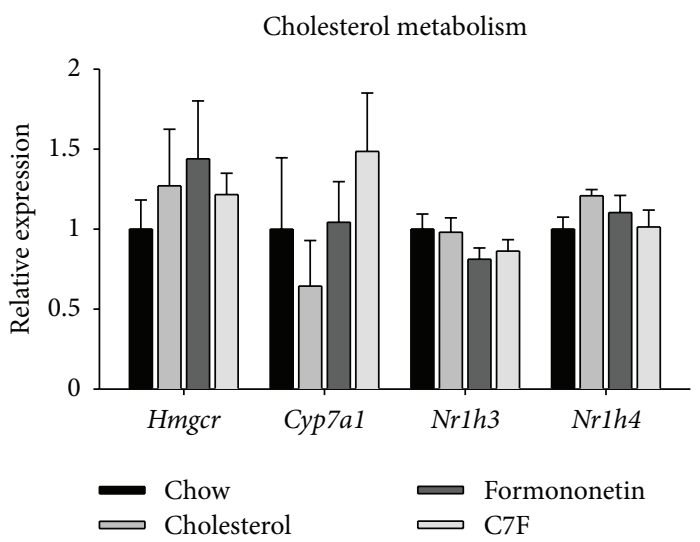

(D)

FIGURE 4: Hepatic gene expression measured by RT-PCR in C57BL/6 mice fed chow, cholesterol, or cholesterol supplemented formononetin or 2-heptyl-formonetin (C7F) for five weeks (Experiment 2). (A) Genes involved in lipogenesis (Srebf1 (sterol regulatory element-binding protein-1c), Mlxipl (carbohydrate response element binding protein), Acaca (acyl-CoA carboxylase 1), Fasn (fatty acid synthase), and Scd1 (stearoyl-CoA desaturase 1)) and synthesis of triglycerides (Gpam (glycerol phosphate acyltransferase) and Dgat2 (diglyceride acyltransferase 2)). (B) Genes involved in hydrolysis and beta-oxidation of fatty acids, Atgl (adipose triglyceride lipase), Ppara (peroxisome proliferatoractivated receptor $\alpha$ ), Cptla (carnitine palmitoyltransferase la), and Acox1 (acyl CoA oxidase). (C) Genes involved in lipoprotein metabolism, Acat2 (acetyl-CoA acetyltransferase), Mttp (microsomal triglyceride transfer protein), and $L d l r$ (low-density lipoprotein receptor). (D) Genes involved in cholesterol metabolism, Hmgcr (3-hydroxy-3-methyl-glutaryl-CoA reductase), Cyp7al (cholesterol 7 alpha-hydroxylase), Nr1 h3 (liver X receptor), and $\mathrm{Nr} 1 \mathrm{~h} 3$ (farnesoid X receptor). Data is normalised to $18 \mathrm{~S}$ ribosomal RNA and presented relative to the expression in chow $(n=6)$. Graphs show mean \pm SEM. Different letters $(a, b, c)$ denote significant difference $(P \leq 0.5)$ between the groups.

expression of Atgl. Mice with liver-specific deletion of Atgl have severe hepatic steatosis but normal plasma levels of glucose, triglycerides, and cholesterol [32]. Thus, deceased lipolysis and $\beta$-oxidation could partly explain the development of hepatic steatosis, especially for mice fed formononetin, although decreased lipogenic gene expression could counteract this effect. In agreement with our results, genistein and daidzein decrease lipogenic gene expression $[14,33]$, whereas the expression of genes involved in $\beta$ oxidation has been decreased in some studies $[34,35]$ but not affected in others $[14,15]$. This suggests that other factors are involved in the increase in hepatic steatosis in this study.

The development of hepatic steatosis can also be caused by decreased export of fatty acids from the liver due to deregulated lipoprotein metabolism. Microsomal triglyceride transfer protein (MTTP) deficient mice have reduced plasma triglycerides levels but develop hepatic steatosis without insulin resistance and inflammation [36]. Similarly, lowdensity lipoprotein receptor (LDLR) deficient mice also develop hepatic steatosis [37]. Thus, although we did not observe a decrease in plasma triglycerides, decreased expression of Mttp and Ldlr could be a major cause of the development of hepatic steatosis in mice fed formononetin and C7F. The effects on lipoprotein metabolism by formononetin and C7F in this study are to a large extent supported by a study in HepG2 cells by Borradaile et al. [38]. In their study genistein and daidzein decreased apolipoprotein $\mathrm{B}$ secretion through decreased MTTP activity and mRNA expression and decreased acetyl-Coenzyme A acetyltransferase activity. However, they report increased expression of $L d l r$. Interestingly, in this study, genistein also increased triglyceride mass in the cells. 


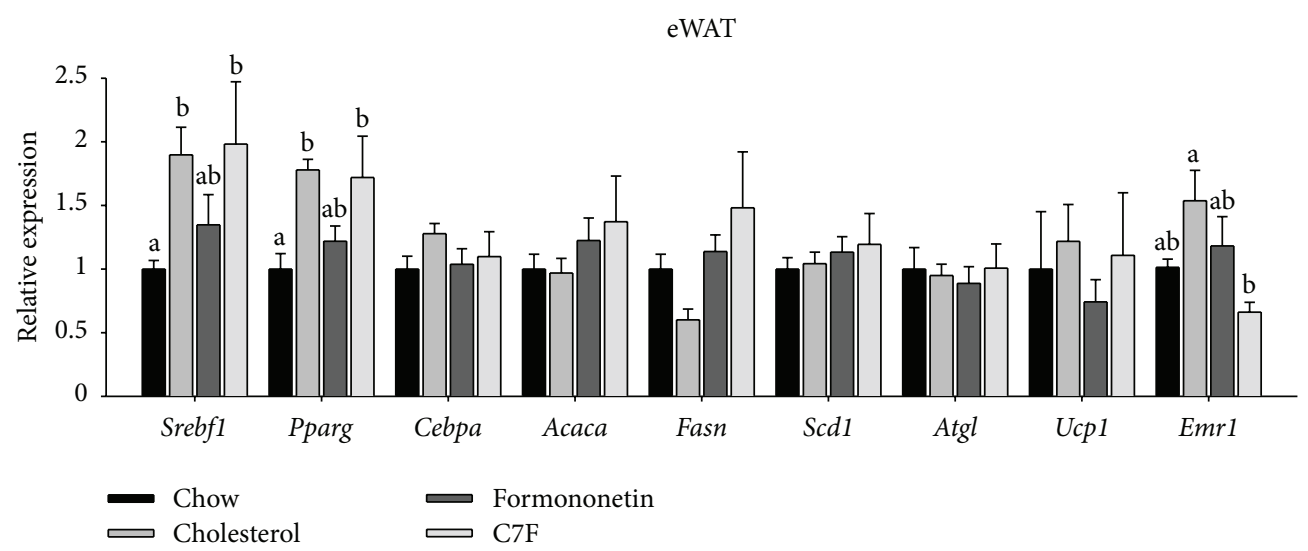

(A)



(B)

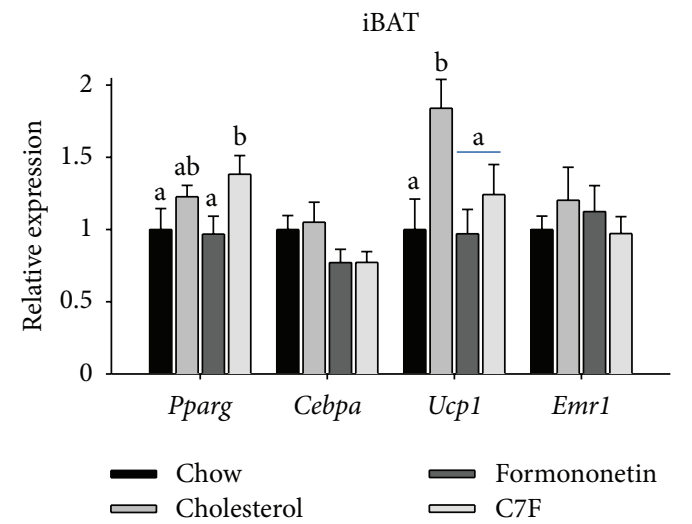

(C)

FIGURE 5: Adipocyte gene expression in C57BL/6 mice fed chow, cholesterol, or cholesterol supplemented formononetin or 2-heptylformonetin (C7F) for five weeks (Experiment 2). Gene expression measured by RT-PCR of Srebfl (sterol regulatory element-binding protein1c), Pparg (peroxisome proliferator-activated receptor $\gamma$ ), Cebpa (CCAAT/enhancer-binding protein $\alpha$ ), Acaca (acyl-CoA carboxylase 1), Fasn (fatty acid synthase), Scd1 (stearoyl-CoA desaturase 1), Atgl (adipose triglyceride lipase), Ucp1 (uncoupling protein 1), and Emr1 (F4/80) in (A) eWAT, (B) iWAT, and (C) iBAT measured by RT-PCR. Data is normalised to $18 \mathrm{~S}$ ribosomal RNA and presented relative to the expression in chow $(n=6)$. Graphs show mean \pm SEM. Different letters $(a, b)$ denote significant difference $(P \leq 0.5)$ between the groups.

Other isoflavones have been shown to decrease lipogenic gene expression in adipocytes both in vitro [39-41] and in vivo $[10,14]$. In 3T3-L1, preadipocytes lower concentrations of C7F increase lipid accumulation, whereas high concentrations decrease lipid accumulation (manuscript in preparation). This response is similar to genistein both in vitro (unpublished results) and in vivo [11]. Based on this study, it is not possible to conclude why C7F, in contrast to other isoflavones, increased lipogenic gene expression in vivo. Both genistein and daidzein have been shown to 
induce lipolysis [40-42]. Increased expression of Atgl by C7F suggests increased lipolysis in iWAT which could explain why there is no increase in fat mass despite increased lipogenic gene expression. Moreover, this could imply a flux of fatty acids from iWAT to the liver.

Despite increased accumulation of triglycerides in the liver, formononetin decreased level of plasma ALT and hepatic expression of Tnf indicating diminished liver damage and lower hepatic inflammation. Furthermore, the decreased expression of Emrl in iWAT and eWAT suggests lower infiltration of macrophages in mice fed formononetin. Isoflavones are known to be anti-inflammatory compounds, and other studies also report decreased plasma levels of AST, ALT, and tumour necrosis factor $\alpha[6,13,43]$ and decreased adipocyte and hepatic expression of $\operatorname{Tnf}[10,43]$. Accumulation of lipids in hepatocytes impairs the oxidative capacity of the mitochondria thereby increasing the generation of reactive oxygen species. Reactive oxygen species trigger lipid peroxidation, release of inflammatory cytokines, and cell death and thereby induce hepatic inflammation and fibrosis [44]. Some of the effects of isoflavones have been attributed to the antioxidative capacity. Yet formononetin has a lower antioxidative capacity than genistein and daidzein [45]. This could partly explain why formononetin and C7F did not prevent hepatic steatosis. Still, the lower levels of plasma ALT and hepatic expression of Tnf in formononetin fed mice compared to C7F fed mice could be due to a higher antioxidative capacity of formononetin than C7F.

In contrast to our results, a range of studies show that plasma total cholesterol, LDL-cholesterol, and triglycerides are decreased by genistein [10,12, 13], daidzein [9], and formononetin [46]. However, LDL is a difficult parameter in mice, as the levels are normally very low and the variation still substantial [9]. Conversely, the effects on HDL-cholesterol vary; some studies show upregulation $[10,13,28]$, one study shows downregulation [12], and two studies show no effect $[14,46]$. Still, based on the development of hepatic steatosis and dysregulated lipid and lipoprotein metabolism, it seems plausible that plasma lipid composition was dysregulated in mice fed formononetin and C7F. The increased plasma level of total cholesterol in mice fed C7F seemed to be caused by a rise in HDL-cholesterol. When LDL circulates in the blood, it can slowly build up in the inner walls of the arteries forming plaques leading to atherosclerosis. In contrast, HDL tends to carry cholesterol away from the arteries and back to the liver. Thus, the increase in HDL-cholesterol could protect against cardiovascular diseases. However, in contrast to humans HDL is the essential cholesterol fraction of mice, whereas the level of LDL-cholesterol is minimal [47]. Therefore, it can be difficult to affect the level of LDL-cholesterol in mice and to extrapolate data on lipid profiles from mice to humans.

Our study suggests that even though bioactive compounds have very similar structures, the biological actions can be very different. It is a possibility that the different actions of formononetin and C7F reported in this study are specifically due to the use of a cholesterol-enriched diet instead of chow and high-fat diets used in other studies. It would therefore be interesting to assess the metabolic effects of genistein and daidzein using other diets like a cholesterolenriched diet to see if this affects the health benefits associated with these compounds.

\section{Conclusions}

In conclusion, we showed that supplementation with formononetin and C7F to C57BL/6J mice fed a cholesterolenriched diet induced hepatic steatosis affecting adipocyte and hepatic gene expression. Of note, in spite of the hepatosteatotic phenotype, formononetin, but not C7F, decreased markers of inflammation and liver injury.

\section{Conflict of Interests}

All authors declare no conflict of interests.

\section{Acknowledgments}

This study was carried out as part of the research program of the UNIK: Food, Fitness \& Pharma for Health and Disease (see http://www.foodfitnesspharma.ku.dk/) supported by the Danish Ministry of Science, Technology and Innovation, and the BEST strategic initiative supported by the Royal Veterinary and Agricultural University. The authors wish to thank Helene Farlov for excellent technical assistance.

\section{References}

[1] C. R. Cederroth and S. Nef, "Soy, phytoestrogens and metabolism: a review," Molecular and Cellular Endocrinology, vol. 304, no. 1-2, pp. 30-42, 2009.

[2] M. S. Kurzer and X. Xu, "Dietary phytoestrogens," Annual Review of Nutrition, vol. 17, pp. 353-381, 1997.

[3] A. Ørgaard and L. Jensen, "The effects of soy isoflavones on obesity," Experimental Biology and Medicine, vol. 233, no. 9, pp. 1066-1080, 2008.

[4] T. Usui, "Pharmaceutical prospects of phytoestrogens," Endocrine Journal, vol. 53, no. 1, pp. 7-20, 2006.

[5] R. P. Patel and S. Barnes, "Isoflavones and PPAR signaling: a critical target in cardiovascular, metastatic, and metabolic disease," PPAR Research, Article ID 153252, 2010.

[6] M. Yalniz, I. H. Bahcecioglu, N. Kuzu et al., "Preventive role of genistein in an experimental non-alcoholic steatohepatitis model," Journal of Gastroenterology and Hepatology, vol. 22, no. 11, pp. 2009-2014, 2007.

[7] K. Taku, K. Umegaki, Y. Sato, Y. Taki, K. Endoh, and S. Watanabe, "Soy isoflavones lower serum total and LDL cholesterol in humans: a meta-analysis of 11 randomized controlled trials," The American Journal of Clinical Nutrition, vol. 85, no. 4, pp. 11481156, 2007.

[8] X. G. Zhuo, M. K. Melby, and S. Watanabe, "Soy isoflavone intake lowers serum LDL cholesterol: a meta-analysis of 8 randomized controlled trials in humans," The Journal of Nutrition, vol. 134, no. 9, pp. 2395-2400, 2004.

[9] M. H. Kim, J. S. Park, J. W. Jung, K. W. Byun, K. S. Kang, and Y. S. Lee, "Daidzein supplementation prevents non-alcoholic fatty liver disease through alternation of hepatic gene expression profiles and adipocyte metabolism," International Journal of Obesity, vol. 35, pp. 1019-1030, 2011. 
[10] M. H. Kim, K. S. Kang, and Y. S. Lee, “The inhibitory effect of genistein on hepatic steatosis is linked to visceral adipocyte metabolism in mice with diet-induced non-alcoholic fatty liver disease," British Journal of Nutrition, vol. 104, no. 9, pp. 13331342, 2010.

[11] M. Penza, C. Montani, A. Romani et al., "Genistein affects adipose tissue deposition in a dose-dependent and gender-specific manner," Endocrinology, vol. 147, no. 12, pp. 5740-5751, 2006.

[12] J. Y. Yang, S. J. Lee, H. W. Park, and Y. S. Cha, "Effect of genistein with carnitine administration on lipid parameters and obesity in C57B1/6J mice fed a high-fat diet," Journal of Medicinal Food, vol. 9, no. 4, pp. 459-467, 2006.

[13] S. S. Mohamed, P. Nallasamy, P. Muniyandi, V. Periyasami, and A. Carani Venkatraman, "Genistein improves liver function and attenuates non-alcoholic fatty liver disease in a rat model of insulin resistance," Journal of diabetes, vol. 1, no. 4, pp. 278-287, 2009.

[14] A. Crespillo, M. Alonso, M. Vida et al., "Reduction of body weight, liver steatosis and expression of stearoyl-CoA desaturase 1 by the isoflavone daidzein in diet-induced obesity," British Journal of Pharmacology, vol. 164, pp. 1899-1915, 2011.

[15] Y. M. Lee, J. S. Choi, M. H. Kim, M. H. Jung, Y. S. Lee, and J. Song, "Effects of dietary genistein on hepatic lipid metabolism and mitochondrial function in mice fed high-fat diets," Nutrition, vol. 22, no. 9, pp. 956-964, 2006.

[16] N. Yumiko, K. Akiko, T. Yukari, I. Susumu, and T. Yasuhide, "Content and composition of isoflavonoids in mature or immature beans and bean sprouts consumed in Japan," Journal of Health Science, vol. 47, pp. 394-406, 2001.

[17] G. Pakalapati, L. Li, N. Gretz, E. Koch, and M. Wink, "Influence of red clover (Trifolium pratense) isoflavones on gene and protein expression profiles in liver of ovariectomized rats," Phytomedicine, vol. 16, no. 9, pp. 845-855, 2009.

[18] P. Shen, M. H. Liu, T. Y. Ng, Y. H. Chan, and E. L. Yong, "Differential effects of isoflavones, from Astragalus Membranaceus and Pueraria Thomsonii, on the activation of $\operatorname{PPAR} \alpha, \operatorname{PPAR} \gamma$, and adipocyte differentiation in vitro," The Journal of Nutrition, vol. 136, no. 4, pp. 899-905, 2006.

[19] S. Zhang, X. Tang, J. Tian et al., "Cardioprotective effect of sulphonated formononetin on acute myocardial infarction in rats," Basic and Clinical Pharmacology and Toxicology, vol. 108, no. 6, pp. 390-395, 2011.

[20] D. S. Pedersen and C. Rosenbohm, "Dry column vacuum chromatography," Synthesis, no. 16, pp. 2431-2434, 2001.

[21] S. A. Schreyer, D. L. Wilson, and R. C. Leboeuf, "C57BL/6 mice fed high fat diets as models for diabetes-accelerated atherosclerosis," Atherosclerosis, vol. 136, no. 1, pp. 17-24, 1998.

[22] J. S. Kang, W. K. Lee, C. W. Lee et al., "Improvement of highfat diet-induced obesity by a mixture of red grape extract, soy isoflavone and l-carnitine: implications in cardiovascular and non-alcoholic fatty liver diseases," Food and Chemical Toxicology, vol. 49, no. 9, pp. 2453-2458, 2011.

[23] P. A. Flecknell, Laboratory Animal Anaesthesia, Academic Press, London, UK, 1996.

[24] S. D. Christensen, L. F. Mikkelsen, J. J. Fels, T. B. Bodvarsdóttir, and A. K. Hansen, "Quality of plasma sampled by different methods for multiple blood sampling in mice," Laboratory Animals, vol. 43, no. 1, pp. 65-71, 2009.

[25] K. Dahl, K. Buschard, D. X. Gram, A. J. F. D’Apice, and A. K. Hansen, "Glucose intolerance in a xenotransplantation model: studies in alpha-gal knockout mice," APMIS, vol. 114, no. 11, pp. 805-811, 2006.
[26] L. Ovreås, L. Forney, F. L. Daae, and V. Torsvik, "Distribution of bacterioplankton in meromictic lake saelenvannet, as determined by denaturing gradient gel electrophoresis of PCRamplified gene fragments coding for 16S rRNA," Applied and Environmental Microbiology, vol. 63, no. 9, pp. 3367-3373, 1997.

[27] H. J. Flint, “Obesity and the gut microbiota," Journal of Clinical Gastroenterology, vol. 45, pp. S128-S132, 2011.

[28] S. Ae Park, M. S. Choi, S. Y. Cho et al., "Genistein and daidzein modulate hepatic glucose and lipid regulating enzyme activities in C57BL/KsJ-db/db mice," Life Sciences, vol. 79, no. 12, pp. 12071213, 2006.

[29] M. S. Choi, U. J. Jung, J. Yeo, M. J. Kim, and M. K. Lee, “Genistein and daidzein prevent diabetes onset by elevating insulin level and altering hepatic gluconeogenic and lipogenic enzyme activities in non-obese diabetic (NOD) mice," Diabetes/Metabolism Research and Reviews, vol. 24, no. 1, pp. 74-81, 2008.

[30] Y. J. Moon, X. Wang, and M. E. Morris, "Dietary flavonoids: effects on xenobiotic and carcinogen metabolism," Toxicology in Vitro, vol. 20, no. 2, pp. 187-210, 2006.

[31] E. Fabbrini, S. Sullivan, and S. Klein, "Obesity and nonalcoholic fatty liver disease: biochemical, metabolic, and clinical implications," Hepatology, vol. 51, no. 2, pp. 679-689, 2010.

[32] J. W. Wu, S. P. Wang, F. Alvarez et al., "Deficiency of liver adipose triglyceride lipase in mice causes progressive hepatic steatosis," Hepatology, vol. 54, no. 1, pp. 122-132, 2011.

[33] E. S. Shin, H. H. Lee, S. Y. Cho, H. W. Park, S. J. Lee, and T. R. Lee, "Genistein downregulates SREBP-1 regulated gene expression by inhibiting site-1 protease expression in HepG2 cells," The Journal of Nutrition, vol. 137, no. 5, pp. 1127-1131, 2007.

[34] S. Kim, I. Sohn, Y. S. Lee, and Y. S. Lee, "Hepatic gene expression profiles are altered by genistein supplementation in mice with diet-induced obesity," The Journal of Nutrition, vol. 135, no. 1, pp. 33-41, 2005.

[35] M. J. Ronis, Y. Chen, J. Badeaux, and T. M. Badger, “Dietary soy protein isolate attenuates metabolic syndrome in rats via effects on PPAR, LXR, and SREBP signaling," The Journal of Nutrition, vol. 139, no. 8, pp. 1431-1438, 2009.

[36] K. Minehira, S. G. Young, C. J. Villanueva et al., "Blocking VLDL secretion causes hepatic steatosis but does not affect peripheral lipid stores or insulin sensitivity in mice," Journal of Lipid Research, vol. 49, no. 9, pp. 2038-2044, 2008.

[37] F. Rodríguez-Sanabria, A. Rull, G. Aragonès et al., "Differential response of two models of genetically modified mice fed with high fat and cholesterol diets: relationship to the study of nonalcoholic steatohepatitis," Molecular and Cellular Biochemistry, vol. 343, no. 1-2, pp. 59-66, 2010.

[38] N. M. Borradaile, L. E. De Dreu, L. J. Wilcox, J. Y. Edwards, and M. W. Huff, "Soya phytoestrogens, genistein and daidzein, decrease apolipoprotein B secretion from HepG2 cells through multiple mechanisms," Biochemical Journal, vol. 366, no. 2, pp. 531-539, 2002.

[39] H. J. Park, M. A. Della-Fera, D. B. Hausman, S. Rayalam, S. Ambati, and C. A. Baile, "Genistein inhibits differentiation of primary human adipocytes," Journal of Nutritional Biochemistry, vol. 20, no. 2, pp. 140-148, 2009.

[40] K. Szkudelska, L. Nogowski, and T. Szkudelski, "Genistein affects lipogenesis and lipolysis in isolated rat adipocytes," Journal of Steroid Biochemistry and Molecular Biology, vol. 75, no. $4-5$, pp. 265-271, 2000.

[41] A. W. Harmon and J. B. Harp, "Differential effects of flavonoids on 3T3-L1 adipogenesis and lipolysis," American Journal of Physiology, vol. 280, no. 4, pp. C807-C813, 2001. 
[42] K. Kandulska, L. Nogowski, and T. Szkudelski, "Effect of some phytoestrogens on metabolism of rat adipocytes," Reproduction Nutrition Development, vol. 39, no. 4, pp. 497-501, 1999.

[43] G. Ji, Q. Yang, J. Hao et al., "Anti-inflammatory effect of genistein on non-alcoholic steatohepatitis rats induced by high fat diet and its potential mechanisms," International Immunopharmacology, vol. 11, no. 6, pp. 762-768, 2011.

[44] A. P. Rolo, J. S. Teodoro, and C. M. Palmeira, "Role of oxidative stress in the pathogenesis of nonalcoholic steatohepatitis," Free Radical Biology and Medicine, vol. 52, no. 1, pp. 59-69, 2012.

[45] C. E. Rüfer and S. E. Kulling, "Antioxidant activity of isoflavones and their major metabolites using different in vitro assays," Journal of Agricultural and Food Chemistry, vol. 54, no. 8, pp. 2926-2931, 2006.

[46] L. Qiu, H. Ye, L. Chen, Y. Hong, F. Zhong, and T. Zhang, "Red clover extract ameliorates dyslipidemia in streptozotocininduced diabetic C57BL/6 mice by activating hepatic PPARalpha," Phytotherapy Research, vol. 26, no. 6, pp. 860-864, 2011.

[47] A. A. Pendse, J. M. Arbones-Mainar, L. A. Johnson, M. K. Altenburg, and N. Maeda, "Apolipoprotein E knock-out and knock-in mice: atherosclerosis, metabolic syndrome, and beyond," Journal of lipid research, vol. 50, pp. S178-182, 2009. 


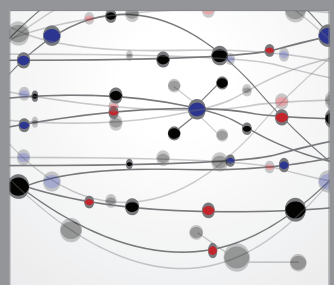

The Scientific World Journal
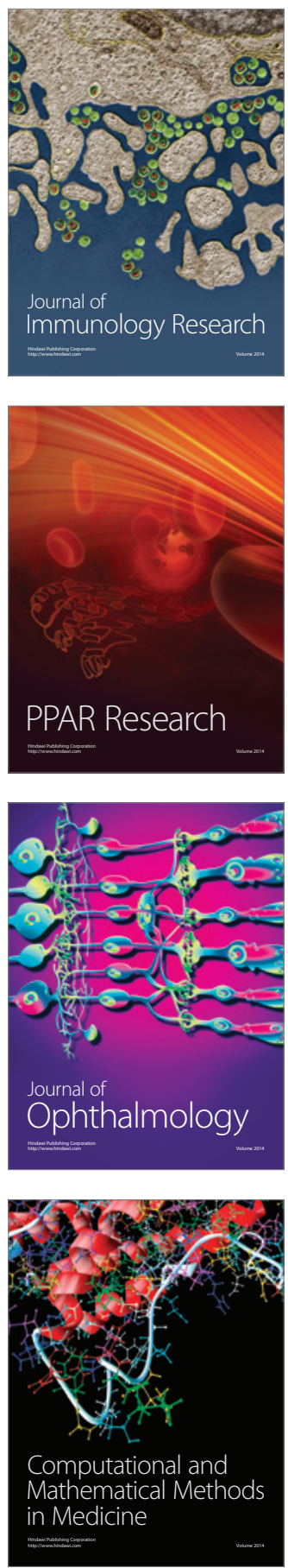

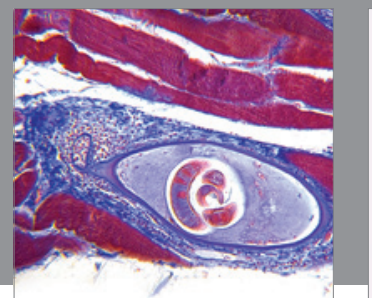

Gastroenterology

Research and Practice
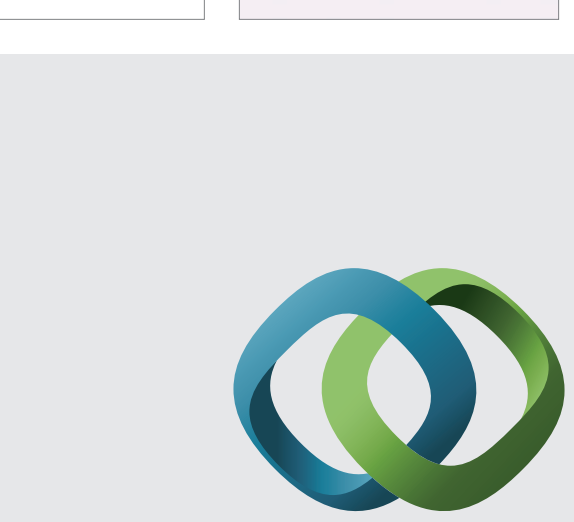

\section{Hindawi}

Submit your manuscripts at

http://www.hindawi.com
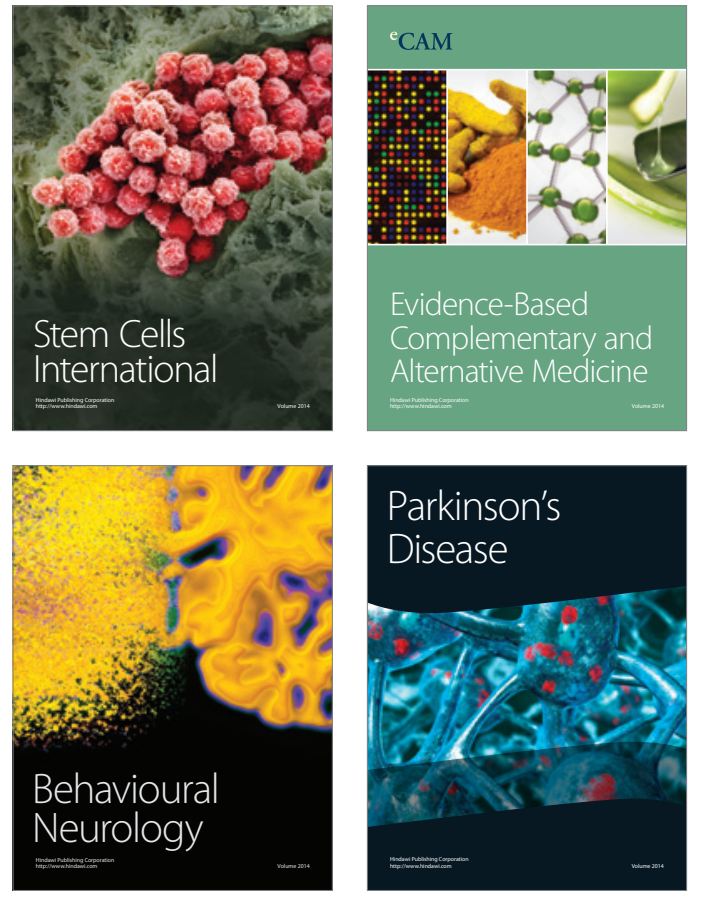
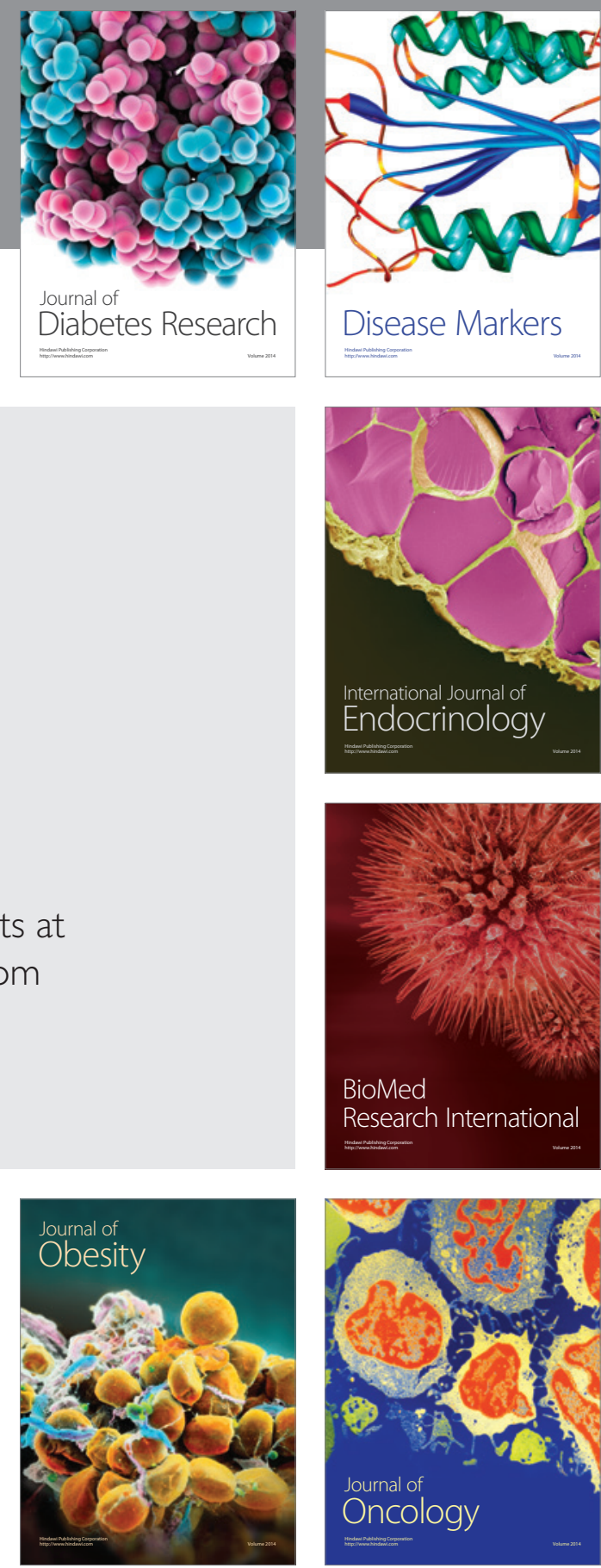

Disease Markers
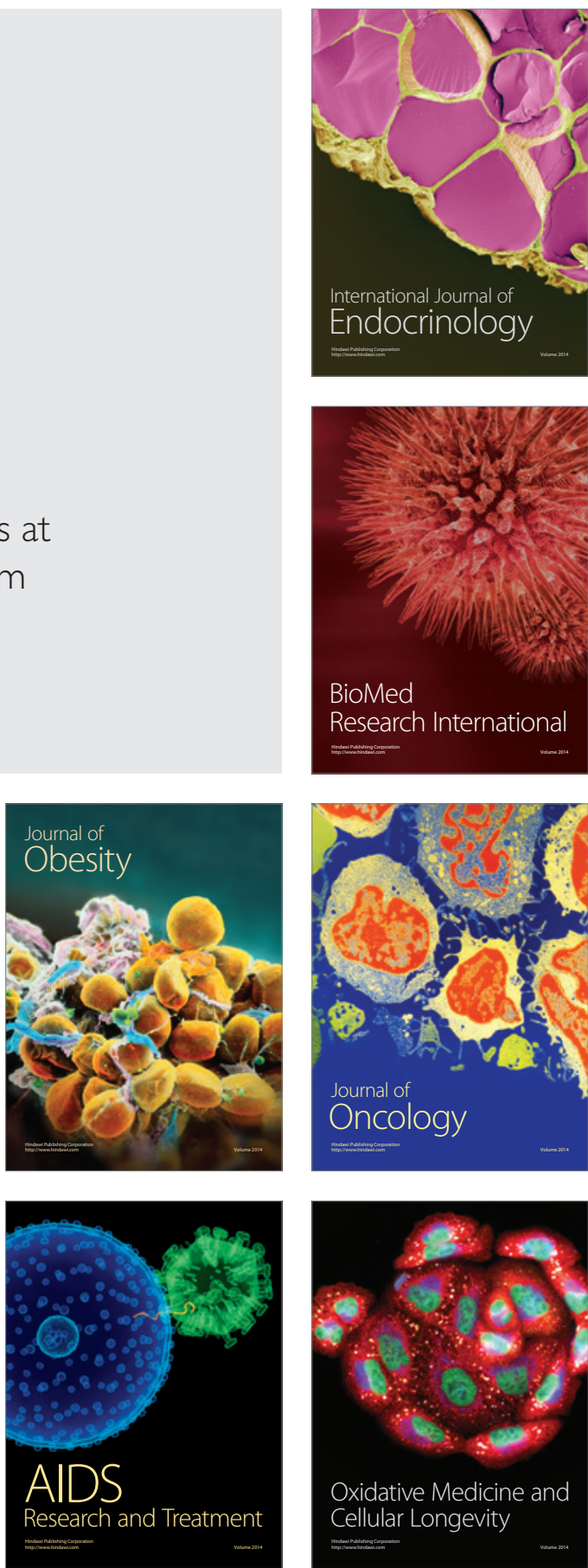